\title{
Supplementing Rural Livelihoods through Backyard Poultry Farming
}

\author{
B.L. Dhaka*, G.S. Meena, R.K. Bairwa and N.L. Meena \\ Krishi Vigyan Kendra, Bundi - 323 001, Rajasthan, India \\ *Corresponding author
}

\begin{tabular}{|c|c|}
\hline & A B S T R A C T \\
\hline Keywords & \multirow{4}{*}{$\begin{array}{l}\text { Backyard poultry has recognized as an effective tool for poverty alleviation in the rural } \\
\text { areas. However, the level of monthly income from backyard poultry is low still it is an } \\
\text { important source of supplementing earnings. It provides eggs and meat for family } \\
\text { consumption and, to some extent, cash income thereby, enhances rural livelihoods. In } \\
\text { order to stimulate economic growth of resource poor household in rural areas of Bundi } \\
\text { district, Rajasthan, low input technology backyard poultry farming was introduced by } \\
\text { Krishi Vigyan Kendra for supplementing earnings of resource poor farmers and landless } \\
\text { labourers. Poultry birds of breed Pratapdhan were provided to farmers. The performance } \\
\text { of birds reared under backyard production system was quite satisfactory. The backyard } \\
\text { poultry farming generated subsistence income and provided valuable foods that improved } \\
\text { household nutrition. }\end{array}$} \\
\hline $\begin{array}{l}\text { Livelihood, } \\
\text { Backyard poultry, } \\
\text { Rural, Farmers. }\end{array}$ & \\
\hline Article Info & \\
\hline $\begin{array}{l}\text { Accepted: } \\
\text { 12 March } 2017 \\
\text { Available Online: } \\
10 \text { April } 2017\end{array}$ & \\
\hline
\end{tabular}

\section{Introduction}

Poor natural resource endowments and limited and inequitable access to productive natural resources is one of the most important drivers of poverty in rural areas. The vicious circle of poverty could not be broken even after planned effort for bringing improvement in the living standard of the rural masses. Despite marginal improvements, resources poor people find it more difficult to exit poverty. In recent years backyard poultry has recognized as an effective tool for poverty alleviation in the rural areas. The role of backyard poultry farming in sustaining and enhancing poor peoples' livelihoods in developing countries is well recognized among the development community (Ahuja et $a l ., 2008)$. There is also growing evidence to demonstrate the role of backyard poultry in enhancing the food and nutrition security of the poorest households, reducing the livelihood vulnerability and insecurity, and promotion of gender equity (Ahuja, 2004; Ahuja and Sen, 2007). However, the level of monthly income from backyard poultry is low still it is an important source of supplementing earnings. It provides eggs and meat for family consumption and, to some extent, cash income thereby, enhances rural livelihoods. Realizing the potential offered by backyard poultry farming Krishi Vigyan Kendra, Bundi initiated to promote backyard poultry through various schemes. In order to stimulate economic growth of resource poor household poultry birds of dual purpose breed Pratapdhan were provided to small and marginal farmers and landless labourers on subsidized rate in rural areas. 


\section{Materials and Methods}

The study was conducted in Bundi district of Rajasthan. In order to understand the role backyard poultry farming in sustaining poor people's livelihoods, this study focused on its contribution to income, household nutrition, and empowerment. Towards that end, this study followed a traditional survey methodology and a qualitative approach.

The formal methods were further supplemented by formal and informal focus group discussions at the community level. The sample units were scattered over various villages of districts. Purposive sampling techniques were used to select sample for the study. Total 30 backyard poultry rearers were selected for the study. Data were collected using a well structured and pre-tested questionnaire. The collected data were statistically analyzed to draw inferences.

\section{Results and Discussion}

\section{Performance of backyard poultry}

Depending upon the agro-ecological conditions, practices of backyard poultry farming vary across study area. Majority of households kept poultry under scavenging conditions resulting in lower unit cost. Accounting for home consumption of poultry meat and eggs, net income per annum per household was estimated to be nearly Rs.28000.00. Households used this increased cash income to pay for educational expenditures, medical emergencies, overcoming food shortages, and other little indulgences of life. This was possible only because backyard poultry farming provided marketable surplus, to some extent, to make it worthwhile for individuals to to meet essential family needs. The finding are corroborate the findings of Ahuja et al., (2008), Meena et al., (2012) and Debnath et al., (2012).

\section{Perceived benefits}

During the promotion of backyard poultry farming it was believed important to convince beneficiaries about the advantages of backyard poultry farming. The beneficiaries came to regard the backyard poultry farming as an important livelihood enhancement that provided many benefits for all. While the benefits of backyard poultry farming were widely known, each respondent had their own perception and priorities.

Table.1 Performance of backyard poultry farming

\begin{tabular}{|l|c|}
\hline Economic traits & Performance \\
\hline Average flock size (No. of birds) & 13 \\
\hline Birds sold / self consumption & 23 \\
\hline Average weight of bird (g) & 2360 \\
\hline Average market price per bird (Rs) & 630 \\
\hline Total Revenue from Birds (Rs) & 14490 \\
\hline Eggs sold / self consumption (No.) & 1898 \\
\hline Average market price per egg (Rs) & 8 \\
\hline Total revenue from eggs (Rs) & 15184 \\
\hline Feed costs (Rs) & 1230 \\
\hline Other costs (Rs) & 244 \\
\hline Total costs (Rs) & 1473 \\
\hline Annual revenue per household (Rs) & 28200 \\
\hline
\end{tabular}


Table.2 Perceived benefits of backyard poultry farming

\begin{tabular}{|l|c|c|}
\hline Benefits & R.B.Q & Overall Rank \\
\hline Alleviates protein malnutrition in vulnerable groups & 58.41 & IV \\
\hline $\begin{array}{l}\text { Waste material can be efficiently converted in to egg and } \\
\text { chicken meat for human consumption }\end{array}$ & 63.26 & III \\
\hline Provides additional income to the rural households & 68.67 & II \\
\hline Integrates well with other agricultural operations & 47.33 & VI \\
\hline Aids in enhancing the soil fertility & 56.89 & V \\
\hline Provides egg and meat with almost no or meager investment & 72.03 & I \\
\hline Generate employment opportunity in rural areas & 46.12 & VII \\
\hline
\end{tabular}

Table.3 Attitude of respondents towards backyard poultry farming

\begin{tabular}{|l|c|c|}
\hline Category & Number & Percentage \\
\hline Highly favourable & 7 & 23.33 \\
\hline Favourable & 17 & 56.67 \\
\hline Neutral & 6 & 20.00 \\
\hline
\end{tabular}

The results presented in table 2 revealed that backyard poultry farming provides egg and meat with almost no or meager investment was emerged as important benefit and given highest priority. The next most frequently mentioned benefit was additional source income to the rural households. Backyard poultry farming can be efficiently convert waste material (insects, ants, fallen grains, green grass, kitchen waste, vegetable waste etc.) in to egg and chicken meat for human consumption was the third most perceived benefit. It was further perceived that it alleviates protein malnutrition in vulnerable groups, aids in enhancing the soil fertility and integrates well with other agricultural operations. Similar benefits were also reported by Obi et al., (2008), Pathak and Nath (2013), Islam et al., (2014), Patel et al., (2014) and Awasthi et al., (2015).

\section{Attitude of farmers}

The attitude of farmers towards backyard poultry farming was measured and results presented in table 3 . The results revealed that majority of the respondents $(56.67 \%)$ possessed favorable attitude towards backyard poultry farming. Results so may be because the respondents were convinced with the benefits reaped from the backyard poultry rearing. However, since the highly favourable category consists of only 23.33 per cent of the respondents, it may also be assumed that the farmers are still not fully convinced of all aspects of backyard poultry farming and that they do have apprehensions on its advantages. Similar results were also reported by Kanwat (2012).

In conclusion it may be concluded that backyard poultry farming is an effective tool for to strengthen the livelihood of resource poor farmers and landless labourers in rural area with low-cost initial investment. It provides eggs and meat for family consumption and additional income to the rural households.

\section{References}

Ahuja, V. (Ed). 2004. Livestock and Livelihoods: Challenges and Opportunities for Asia in the Emerging 
Market Environment, National Dairy Development Board of Indian and Food and Agriculture Organization of the United Nations. p. 372.

Ahuja, V. and Sen, A. 2007. Viability and future of small scale commercial poultry production in developing countries. paper presented at International Conference on Poultry in the 21st Century: Avian Influenza and Beyond, Bangkok, November 5-7, 2007.

Ahuja, V., Dhawan, M., Punjabi, M. and Maarse, L. 2008. Poultry based livelihoods of rural poor: Case of Kuroiler in West Bengal. National Dairy Development Board of Indian and Food and Agriculture Organization of the United Nations, p.57.

Awasthi, P.K., Tomar, A. and Raghuwanshi, N.K. 2015. Poverty reduction through strengthening backyard poultry farming in central India: an economic analysis. Int. J. Food, Agri. Vet. Sci., 5(1): 11-17.

Debnath, M.K., Majumder, D. and Das, P.K. 2011. Status of backyard and small scale poultry production to sustainable livelihood- a case study. J. Crop and Weed, 7(2): 113-115.
Islam, R., Kalita, N. and Nath, P. 2014. Comparative performance of Vanaraja and Indigenous chicken under backyard system of rearing. J. Poultry Sci. Technol., 2(1): 22-25.

Kanwat, M., Meena, M.S., Kumar, P.S., Choudhary, V.K. and Bhagawati, R. 2012. Measurement of attitude towards the adoption of back yard poultry farming in arunachal pradesh. J. Agri. Sci., 4(3): 131-136.

Meena, K.C., Singh, B. and Shivhare, M.K. 2012. Nutritional and livelihood security through backyard poultry for small and landless labours. Current Opinion in Agri., 1(1): 24-26.

Patel, S.K., Machhar, R.G., Kacha, H.L., Rani, R.R., Patel, G.D. and Patel, U.M. 2014. Effect of backyard poultry farming on living standard of tribal farmers in Dahod district of Gujarat, India. J. Poultry Sci. Technol., 2(4): 7983.

Pathak, P.K. and Nath, B.G. 2013. Rural poultry farming with improved breed of backyard chicken. J. World's Poult. Res., 3(1): 24-27.

\section{How to cite this article:}

Dhaka, B.L., G.S. Meena, R.K. Bairwa and Meena, N.L. 2017. Supplementing Rural Livelihoods through Backyard Poultry Farming. Int.J.Curr.Microbiol.App.Sci. 6(4): 14121415. doi: https://doi.org/10.20546/ijcmas.2017.604.172 